\title{
Manejo de Plantas Daninhas Eudicotiledôneas na Cultura da SOJA ROUNDUP READY ${ }^{\circledR 1}$
}

\author{
Management of Eudicotyledonous Weeds in Roundup Ready Soybeans ${ }^{\circledR}$ \\ RIZZARDI, M.A. ${ }^{2}$ e SILVA, L. ${ }^{3}$
}

\begin{abstract}
RESUMO - As espécies eudicotiledôneas sempre foram um desafio no manejo de plantas daninhas na cultura da soja. Essa dificuldade foi aumentada pelo surgimento de plantas de difícil controle com os herbicidas atualmente existentes no mercado. Diante disso, o objetivo deste trabalho foi o de buscar alternativas de manejo que diminuam a pressão de seleção devido ao uso contínuo de glifosato na soja Roundup Ready ${ }^{\mathbb{}}$. O trabalho foi implantado no delineamento em blocos casualizados, em esquema de parcelas sub-subdivididas, com quatro repetições. Foram avaliadas cinco coberturas de inverno (parcelas), seis manejos químicos em pré-semeadura da soja (subparcelas) e três manejos químicos em pós-emergência da soja (sub-subparcelas). Nenhum dos tratamentos avaliados mostrou fitotoxicidade visual às plantas de soja. No entanto, as aplicações sequenciais em pós-emergência diminuíram a altura da soja, mas sem impactar negativamente a sua produtividade. Nos tratamentos com cobertura de aveia, trigo ou azevém, qualquer combinação de aplicações em pré e póssemeadura propiciou controle de buva acima de $90 \%$. De maneira geral, os tratamentos que propiciaram os maiores controles para leiteiro foram as combinações de glifosato + diclosulam e glifosato + sulfentrazone em pré-semeadura. Quando a soja foi semeada em área de pousio de inverno, a produtividade foi em média $8 \%$ inferior do que quando semeada em áreas com cobertura de aveia e trigo. De modo geral, os tratamentos que resultaram em maiores produtividades foram aqueles em que se utilizou glifosato + diclosulam ou glifosato + sulfentrazone na pré-semeadura da soja.
\end{abstract}

Palavras-chave: culturas de cobertura, herbicidas, Euphorbia heterophylla, Conyza bonariensis.

\begin{abstract}
Broadleaf weeds have always been and still remain, from the point of view of weed management, a major challenge for the technicians and farmers who work with soybean. This study aims at seeking alternative management for these species within a production system using RR soybeans. The experiment was conducted in a randomized block design in a sub-plot with four replications subdivided wherein five winter cover plots, six management chemical pre-sowing soybean subplots, and three management chemical post-emergence soybean sub-subplots were tested. None of the treatments proved to be phytotoxic to soybean plants. The sequential applications postemergence showed a trend of reduction of plant height, which did not negatively impact the productivity of the plots. In treatments with a coverage of oats, wheat, or ryegrass, any combination of managements in pre- and post-sowing returned horseweed control values above 90\%. In general, the best treatment for the control of Euphorbia as the combinations of glyphosate and glyphosate + diclosulam or sulfentrazone in pre-planting soybeans. When soybeans are planted in fallow areas, productivity is on average $8 \%$ lower than when sown in areas with coverage of oats or wheat. In general, treatments that returned the highest yields were implanted using glyphosate or glyphosate + diclosulam or sulfentrazone in pre-planting soybeans.
\end{abstract}

Keywords: cover crops, weeds, Euphorbia heterophylla, Conyza bonariensis.

Recebido para publicação em 6.3.2014 e aprovado em 23.7.2014.

Universidade de Passo Fundo, Passo Fundo-RS, Brasil, <rizzardi@upf.br>; ${ }^{3}$ Monsanto do Brasil, Passo Fundo-RS, Brasil.

Planta Daninha, Viçosa-MG, v. 32, n. 4, p. 683-697, 2014 


\section{INTRODUÇÃO}

A soja é uma das culturas de maior importância econômica para o Brasil, e várias espécies de plantas daninhas afetam sua produtividade. Entre estas, as eudicotiledôneas, conhecidas vulgarmente por folhas largas, causam prejuízos significativos na produtividade. Isso ocorre devido às dificuldades de seu controle, seja pela similaridade com a cultura, pela tolerância natural dessas espécies aos herbicidas ou pelas recentes descobertas de plantas com resistência ao glifosato, principal herbicida utilizado atualmente em soja transgênica $\left(\right.$ Roundup Ready $\left.{ }^{\circledR}\right)$, que representa aproximadamente $75 \%$ de toda a soja cultivada no País (Clive, 2010). Esse cenário gera pressão de seleção extremamente alta, o que acaba culminando com a seleção de espécies tolerantes e de biótipos resistentes a esse herbicida.

Indiscutivelmente, a possibilidade de uso de cultivares com a característica de tolerância ao glifosato trouxe à agricultura nacional novo cenário em termos de facilidade de condução das lavouras de soja. No entanto, a adoção de sistemas de produção relativamente simples gera ambiente favorável ao surgimento de plantas daninhas resistentes e mudança da flora daninha (Buhler, 2002). Em decorrência disso, o manejo dessas espécies vai muito além da simples utilização de produtos químicos para o controle pontual das plantas que infestam a lavoura em determinado momento.

Entre as várias estratégias de manejo para evitar a resistência de plantas daninhas a herbicidas citadas na literatura estão: a utilização de herbicidas com diferentes mecanismos de ação, a realização de aplicações sequenciais, o uso de misturas de herbicidas com diferentes mecanismos de ação e a adoção do sistema de plantio direto, trazendo com ele os beneficios das plantas de cobertura, da palhada e da rotação de culturas (Vargas et al., 1999; Vidal \& Merotto Jr., 2001; Roman et al., 2007).

No Brasil, inúmeros são os relatos de plantas daninhas que causam perdas de produtividade em soja. Entre as plantas daninhas eudicotiledôneas, destacam-se Euphorbia heterophylla (leiteiro) e Conyza spp. (buvas) (Vargas \& Roman, 2008).
A espécie E. heterophylla, conhecida como leiteiro ou amendoim-bravo, pertence à família Euphorbiaceae, sendo uma planta anual, herbácea, ereta e produtora de látex (Kissmann \& Groth, 1999). De dificil controle por herbicidas, foi considerada por Cardenas (1972) como mediamente nociva, já tendo alguns biótipos resistentes (resistência cruzada) a herbicidas inibidores da enzima acetolactato sintase (ALS) e da enzima protoporfirinogênio IX oxidase (PROTOX) (Vargas et al., 1999; Trezzi et al., 2009), além da suspeita de uma possivel resistência aos inibidores de EPSPS (Vidal et al., 2007). Essa espécie é comumente citada como uma das mais importantes infestantes da cultura da soja no Rio Grande do Sul. Em levantamento efetuado no planalto do Estado do RS foi constatado que $74,0 \%$ das áreas de soja apresentavam-se infestadas com essa espécie (Vidal \& Winkler, 2002). No Brasil, mais de 20 milhões de hectares são tratados para controle dessa planta daninha (Kissmann \& Groth, 1999).

As espécies Conyza spp., conhecidas popularmente por buva, pertencem à família Asteraceae. São plantas anuais, herbáceas, eretas e com reprodução por sementes que germinam no outono/inverno, com encerramento do ciclo na primavera e verão (Kissmann \& Groth, 1999; Weaver, 2001). São de dificil controle, especialmente através do método químico, seja por tolerância natural ou pelo desenvolvimento de resistência aos herbicidas. Devido a isso, práticas de manejo requerem a combinação de múltiplas ações, como: solo permanentemente coberto, uso rotineiro da rotação de culturas e adoção de técnicas culturais apropriadas (Lazaroto et al., 2008).

Objetivou-se com este trabalho identificar estratégias de manejo para prevenção do surgimento de novos casos de plantas daninhas resistentes ao herbicida glifosato, especialmente para a espécie E. heterophylla.

\section{MATERIAL E MÉTODOS}

O trabalho foi conduzido em solo classificado como Latossolo Vermelho distrófico típico (Embrapa, 1999). O clima da região, segundo Köppen, é classificado como subtropical úmido, 
tipo Cfa2, com altitude aproximada de 560 metros. As coordenadas da área experimental são: latitude de $28^{\circ} 24^{\prime} 57.06^{\prime \prime S ~ e ~}$ longitude de 5249’4.91"O.

Antes do estabelecimento do experimento, fez-se a análise de solo na camada de $0-10 \mathrm{~cm}$, que indicou as seguintes características fisicas e químicas: argila, 35\%; $\mathrm{pH}$ em água, 5,5; Ca, 5,2 $\mathrm{cmol}_{\mathrm{c}} \mathrm{dm}^{-3}$; $\mathrm{Mg}, 1,5 \mathrm{cmol}_{\mathrm{c}} \mathrm{dm}^{-3}$; Al, 0, $1 \mathrm{cmol}_{\mathrm{c}} \mathrm{dm}^{-3} ; \mathrm{H}+\mathrm{Al}, 5,5 \mathrm{cmol}_{\mathrm{c}} \mathrm{dm}^{-3}$; CTC pH7, 12,8 $\mathrm{cmol}_{\mathrm{c}} \mathrm{dm}^{-3}$; SMP, 5,8; saturação por Al, 1,0\%; saturação por bases, $57,0 \%$; $\mathrm{P}, 31,0 \mathrm{mg} \mathrm{dm}^{-3}$; K, 245,0 mg dm${ }^{-3}$ e MO, 2,8\%.

O experimento foi conduzido no delineamento em blocos casualizados, em esquema de parcela sub-subdividida, com quatro repetições, onde foram testados três fatores. O fator A, composto por cinco coberturas de inverno (trigo, aveia, azevém, pousio manejado e pousio), foi testado nas parcelas. Seis controles químicos em pré-semeadura da soja (glifosato, glifosato $+2,4-\mathrm{D}$, glifosato + sulfentrazone, glifosato + diclosulam, diuron + paraquat e testemunha) compuseram o fator B e foram testados nas subparcelas; e o fator $\mathrm{C}$, composto por três controles químicos em pós-emergência da soja (glifosato sequencial, glifosato e testemunha), foi testado nas sub-subparcelas. Os niveis dos fatores B e C estão detalhados na Tabela 1 .

Cada sub-subparcela foi composta por oito linhas de $5 \mathrm{~m}$ de comprimento, no espaçamento de $45 \mathrm{~cm}$, perfazendo $18 \mathrm{~m}^{2}$. Das oito linhas de cada sub-subparcela, duas linhas (linhas 7 e 8) foram consideradas como testemunha lateral, e as avaliações (visuais e de colheita) foram realizadas nas linhas 3 e 4, perfazendo $4,5 \mathrm{~m}^{2}$ de área útil por sub-subparcela.

$\mathrm{O}$ experimento foi conduzido em área de resteva de soja. Após a colheita da soja, realizada em meados do mês de maio, foram implantados os tratamentos de inverno (culturas de cobertura ou pousio). As parcelas em pousio sofreram uma única interferência 41 dias antes da semeadura (DAS) da soja, momento em que foi realizada a dessecação com 1.440 g e.a. ha-1 de glifosato.

O tratamento denominado pousio manejado, além da aplicação de 1.440 g e.a. ha-1 de glifosato aos 41 DAS, recebeu uma aplicação de 1.440 g e.a. ha ${ }^{-1}$ de glifosato $+3,6$ g i.a. ha ${ }^{-1}$ de metsulfurom-metílico no período compreendido entre a colheita da soja e antes que qualquer planta infestante apresentasse florescimento, o que ocorreu aos 114 DAS.

A semeadura do azevém (Lolium multiflorum) e da aveia-preta (Avena strigosa) foi realizada em 26 de maio, utilizando-se semeadora de plantio direto regulada para distribuir 100 e $120 \mathrm{~kg} \mathrm{ha}^{-1}$ de sementes de azevém e aveia, respectivamente, no espaçamento de $17 \mathrm{~cm}$ entre linhas. A aveia-preta e o azevém foram dessecados aos 41 DAS da soja com 1.440 g e.a. ha-1 de glifosato.

O trigo foi implantado e manejado seguindo-se as recomendações da comissão de pesquisa do trigo para a região Sul do Brasil. Foi utilizado o cultivar Abalone, na quantidade de $150 \mathrm{~kg} \mathrm{ha}^{-1}$ de sementes, semeadas com semeadora de plantio direto, com espaçamento de $17 \mathrm{~cm}$ entre linhas e utilizando-se 43,4 kg ha-1 de $\mathrm{N}, 111,6 \mathrm{~kg} \mathrm{ha}^{-1}$ de $\mathrm{P}_{2} \mathrm{O}_{5}$ e $31,0 \mathrm{~kg} \mathrm{ha}^{-1}$ de $\mathrm{K}_{2} \mathrm{O}$. Realizou-se a colheita do trigo com colhedora de parcelas, em novembro (28 DAS da soja).

Com exceção do tratamento de glifosato + 2,4-D, que foi aplicado aos 22 DAS da soja, os demais tratamentos testados em présemeadura da soja foram aplicados no dia da semeadura. O tratamento glifosato $+2,4-\mathrm{D}$ havia sido programado para ser aplicado aos 7 DAS da soja, mas, em razão do período muito chuvoso no mês de novembro que sucedeu a aplicação deste tratamento, a semeadura da soja somente foi possivel aos 22 dias após sua realização (Figura 1).

A semeadura da soja foi feita no mesmo dia para todos os tratamentos, $7 \mathrm{de}$ dezembro, 28 dias após a colheita do trigo. A soja cultivar BMX Apolo foi semeada com semeadora de quatro linhas para plantio direto, com espaçamento entre linhas de $45 \mathrm{~cm}$ e regulada para distribuir 16 sementes $\mathrm{m}^{-1}$. A emergência da soja ocorreu em 14 de dezembro.

Tanto os tratamentos de pré-semeadura quanto os de pós-emergência foram aplicados utilizando-se pulverizador costal de pressão constante pressurizado a $\mathrm{CO}_{2}$, com barra contendo seis bicos de pulverização modelo TeeJet TT110015, distantes $50 \mathrm{~cm}$, operando 
Tabela 1 - Ingredientes ativos e doses utilizadas nas aplicações de pré-semeadura (fator B) e pós-emergência (fator C) da soja

\begin{tabular}{|c|c|c|c|c|c|}
\hline \multicolumn{3}{|c|}{ Pré-semeadura } & \multicolumn{3}{|c|}{ Pós-emergência } \\
\hline Tratamento $^{\underline{1} /}$ & $\mathrm{DAS}^{2 /}$ & Dose ( g i.a. ou g e.a. ha ${ }^{-1}$ ) & Tratamento $^{\underline{1 /}}$ & Estádio & Dose (g e.a. ha $\left.{ }^{-1}\right)$ \\
\hline Testemunha & - & - & Testemunha & - & - \\
\hline Testemunha & - & - & Glifosato & $\mathrm{V}_{3}$ & 960 \\
\hline Testemunha & - & - & Glifosato/glifosato & $\mathrm{V}_{3} / \mathrm{V}_{6}$ & $960 / 720$ \\
\hline Glifosato & 0 & 1300 & Testemunha & - & - \\
\hline Glifosato & 0 & 1300 & Glifosato & $\mathrm{V}_{3}$ & 960 \\
\hline Glifosato & 0 & 1300 & Glifosato/glifosato & $\mathrm{V}_{3} / \mathrm{V}_{6}$ & $960 / 720$ \\
\hline Glifosato + sulfentrazone & 0 & $1300+200$ & Testemunha & - & - \\
\hline Glifosato + sulfentrazone & 0 & $1300+200$ & Glifosato & $\mathrm{V}_{3}$ & 960 \\
\hline Glifosato + sulfentrazone & 0 & $1300+200$ & Glifosato/glifosato & $\mathrm{V}_{3} / \mathrm{V}_{6}$ & $960 / 720$ \\
\hline Glifosato + diclosulam & 0 & $1300+30$ & Testemunha & - & - \\
\hline Glifosato + diclosulam & 0 & $1300+30$ & Glifosato & $\mathrm{V}_{3}$ & 960 \\
\hline Glifosato + diclosulam & 0 & $1300+30$ & Glifosato/glifosato & $\mathrm{V}_{3} / \mathrm{V}_{6}$ & $960 / 720$ \\
\hline Diuron + paraquat & 0 & $200+400$ & Testemunha & - & - \\
\hline Diuron + paraquat & 0 & $200+400$ & Glifosato & $\mathrm{V}_{3}$ & 960 \\
\hline Diuron + paraquat & 0 & $200+400$ & Glifosato/glifosato & $\mathrm{V}_{3} / \mathrm{V}_{6}$ & $960 / 720$ \\
\hline Glifosato + 2,4-D & 22 & $1300+1005$ & Testemunha & - & - \\
\hline Glifosato + 2,4-D & 22 & $1300+1005$ & Glifosato & $\mathrm{V}_{3}$ & 960 \\
\hline Glifosato + 2,4-D & 22 & $1300+1005$ & Glifosato/glifosato & $\mathrm{V}_{3} / \mathrm{V}_{6}$ & $960 / 720$ \\
\hline
\end{tabular}

1/ “+” = associação; " "” = sequencial; 2 / DAS = dias antes da semeadura da soja.

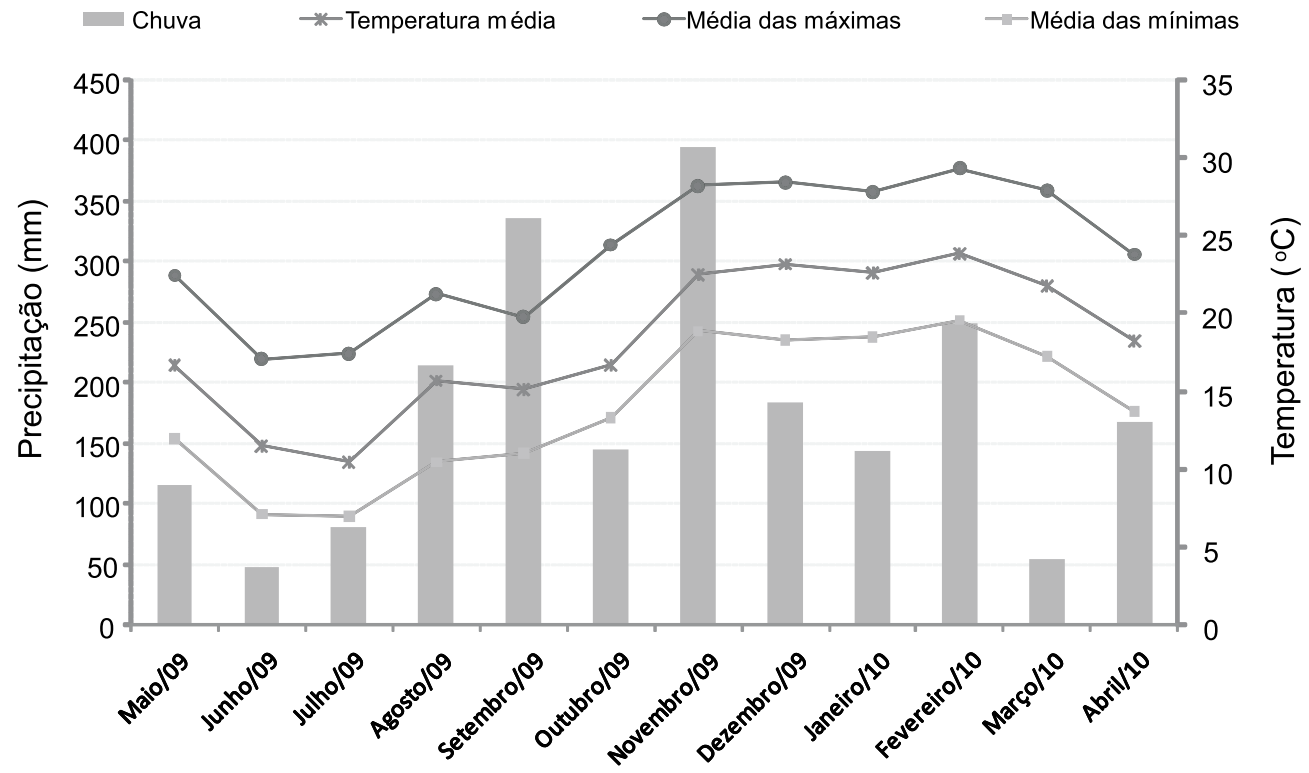

Figura 1 - Precipitação pluvial (mm) e temperatura média, média das máximas e média das mínimas $\left({ }^{\circ} \mathrm{C}\right)$, entre maio de 2009 e abril de 2010. Dados: Cotrijal.

à pressão de $1,0 \mathrm{kgf} \mathrm{cm}^{-2}$, gerando um volume de calda de $110 \mathrm{~L} \mathrm{ha}^{-1}$.

O controle de plantas daninhas gramíneas foi obtido com o herbicida graminicida clethodim (120 $\left.\mathrm{g} \mathrm{ha}^{-1}\right)$, acrescido do adjuvante Assist a $0,5 \% \mathrm{v} / \mathrm{v}$.

O tratamento composto por uma única aplicação de glifosato em pós-emergência foi 
realizado no momento em que as plantas de soja apresentavam a segunda folha trifoliolada completamente desenvolvida (estádio $\mathrm{V}_{3}$ ). O tratamento com aplicação sequencial foi realizado no momento em que as plantas de soja apresentavam-se com o segundo e quinto trifólios completamente desenvolvidos: estádio $\mathrm{V}_{3}$ e $\mathrm{V}_{6}$, respectivamente.

A estimativa de produção de matéria seca (MS) em $\mathrm{kg} \mathrm{ha}^{-1}$ pelas coberturas de inverno foi realizada no momento da semeadura da soja, sendo coletadas amostras de $0,25 \mathrm{~m}^{2} \mathrm{em}$ cinco pontos aleatórios de cada parcela principal (pousio manejado, pousio, trigo, azevém e aveia), com auxílio de um quadrado de $0,5 \times 0,5 \mathrm{~m}$. A produção de MS foi estimada através da secagem das amostras em estufa com circulação forçada de ar à temperatura de $70{ }^{\circ} \mathrm{C}$, até atingirem massa constante, as quais foram pesadas para posterior estimativa desse parâmetro.

A avaliação da infestação (plantas $\mathrm{m}^{-2}$ ) e do estádio de desenvolvimento (folhas por planta) das plantas daninhas foi realizada em dois momentos: a primeira, por ocasião da dessecação das coberturas, o que ocorreu aos 41 DAS da soja, e a segunda, por ocasião da semeadura. Em ambos os momentos, a avaliação de infestação foi feita pelo método do quadrado, em área de $0,25 \mathrm{~m}^{2}$, através da contagem do número de plantas em 10 pontos aleatórios dentro de cada parcela principal e, posteriormente, estimando o número de plantas $\mathrm{m}^{-2}$. O estádio das plantas foi avaliado nos mesmos momentos e pontos da avaliação de infestação, anotando-se o número médio de folhas das plantas dentro da amostra.

A avaliação de estande da soja foi feita no estádio $\mathrm{V}_{2}$ e na pré-colheita, por meio da contagem do número de plantas das linhas 3 e 4 de cada sub-subparcela. No estádio $V_{4}$, após a constatação de que não havia efeito significativo das coberturas de inverno nem dos tratamentos de pré-semeadura, foi realizada a padronização do estande para 10 plantas $\mathrm{m}^{-1}$ em todos os tratamentos, sendo esta realizada nas duas linhas centrais da parcela (linhas 3 e 4).

Para avaliação de controle, foram dadas notas visuais de 0 a $100 \%$, em que a nota 0 representa a ausência de controle e 100 a morte total das plantas daninhas na parcela. Essa avaliação foi realizada em dois momentos: uma aos 28 dias após aplicação sequencial (DAAS) e outra no estádio R6 da soja, em pleno enchimento das vagens, que engloba todos os manejos realizados e representa todo o periodo de possivel interferência das infestantes com a soja.

A fitotoxicidade foi avaliada por meio da observação visual, com atribuição de notas de acordo com os sintomas apresentados pelas plantas aos 28 DAAS. As notas representam a média de quatro repetições e foram atribuídas com base na escala de notas da European Weed Research Council (EWRC), em que: 1: sem dano; 2: pequenas alterações (descoloração, deformação) visíveis em algumas plantas; 3: pequenas alterações (descoloração, deformação) visíveis em muitas plantas; 4: forte descoloração (amarelecimento) ou razoável deformação, sem, contudo, ocorrer necrose (morte do tecido); 5: necrose (queima) de algumas folhas, em especial nas margens, acompanhada de deformação em folhas e brotos; 6: mais de 50\% das folhas e brotos apresentando necrose (deformação); 7: mais de 80\% das folhas e brotos destruídos; 8: danos extremamente graves, sobrando apenas pequenas áreas verdes nas plantas; e 9: morte da planta.

Na pré-colheita da soja, avaliou-se a altura das plantas, medindo-se a distância desde o solo até o último nó desenvolvido no caule, de 10 plantas escolhidas ao acaso na linha 2 , com o auxílio de régua graduada.

A produtividade da soja $\left(\mathrm{kg} \mathrm{ha}^{-1}\right)$ foi estimada através da colheita manual das linhas 3 e 4 das sub-subparcelas, correspondendo a uma área de $2,25 \mathrm{~m}^{2}$. Após o corte, as plantas foram debulhadas e os grãos, pesados, para estimativa da produtividade, corrigindo-se o rendimento de grãos para teor de umidade de $13 \%$.

Os dados obtidos foram submetidos à análise de variância. Obtendo-se significância em nivel de $5 \%$ de probabilidade, a análise teve continuidade, com a aplicação do teste de Tukey. As análises foram realizadas com auxilio do programa estatístico SISVAR. 


\section{RESULTADOS E DISCUSSÃO}

O efeito das coberturas de inverno foi significativo para a produção de MS, com diferenças entre as coberturas. As duas espécies que produziram a maior quantidade de MS foram aveia $\left(3.508,8 \mathrm{~kg} \mathrm{ha}^{-1}\right)$ e trigo $(3.094,6$ $\mathrm{kg} \mathrm{ha} \mathrm{h}^{-1}$, e não houve diferença significativa entre elas (Figura 2). As parcelas com cobertura de azevém proporcionaram em média $2.059 \mathrm{~kg} \mathrm{ha}^{-1}$ de MS, sendo um valor intermediário de produção de palhada quando comparado com os demais tratamentos testados.

Os dois tratamentos em que as parcelas ficaram em pousio (pousio e pousio manejado) tiveram a menor produção de MS (Figura 3). No pousio, a produção foi de $1.245,8 \mathrm{~kg} \mathrm{ha}^{-1}$, bastante similar aos valores encontrados por Gonçalves et al. (2000) e Aita et al. (2001), de 1.840 e $1.197 \mathrm{~kg} \mathrm{ha}^{-1}$ respectivamente. No entanto, a parcela correspondente ao pousio manejado - que recebeu uma aplicação química no intervalo compreendido entre a colheita da soja na safra passada e a dessecação para o plantio da safra correspondente a este experimento - gerou quantidade de MS de apenas $7 \%$ (243 $\mathrm{kg} \mathrm{ha}{ }^{-1}$ ), em comparação com as coberturas de aveia ou trigo, sendo a que apresentou a menor cobertura de solo entre todas as coberturas de inverno testadas durante todo o período de condução do experimento.

Entre os vários pilares de sustentação do sistema de plantio direto estão a diversificação de espécies via rotação/consorciação de culturas e a manutenção permanente de cobertura do solo. Esse sistema fundamentase na produção de elevada quantidade de MS para cobertura do solo (Silva et al., 2006), proporcionando redução significativa na infestação de plantas daninhas e modificando a composição da população infestante (Mateus et al., 2004). Paula et al. (2011) observaram que o trigo e a aveia-preta exercem efeito supressor sobre a população de C. bonariensis, proporcionando maior facilidade de controle com o herbicida na pré-semeadura da cultura usada em sucessão.

A avaliação realizada no momento de dessecação das coberturas de inverno (27 de outubro) mostrou que o efeito de tratamento foi significativo tanto para o número de plantas por metro quadrado (infestação) quanto para o número de folhas por planta (estádio) de E. heterophylla. A eliminação da vegetação espontânea das parcelas de pousio manejado (15 de agosto) fez com que as sementes de E. heterophylla germinassem e infestassem a área em maior número quando comparado com as demais parcelas com cobertura vegetal, mesmo quando comparado com as parcelas de pousio sem manejo, que tinham menor cobertura vegetal (em comparação com as parcelas de trigo, aveia ou azevém); contudo, mesmo assim, é suficiente para suprimir a germinação das sementes de E. heterophylla (Figura 3). Isso pode ser explicado pelo fato de

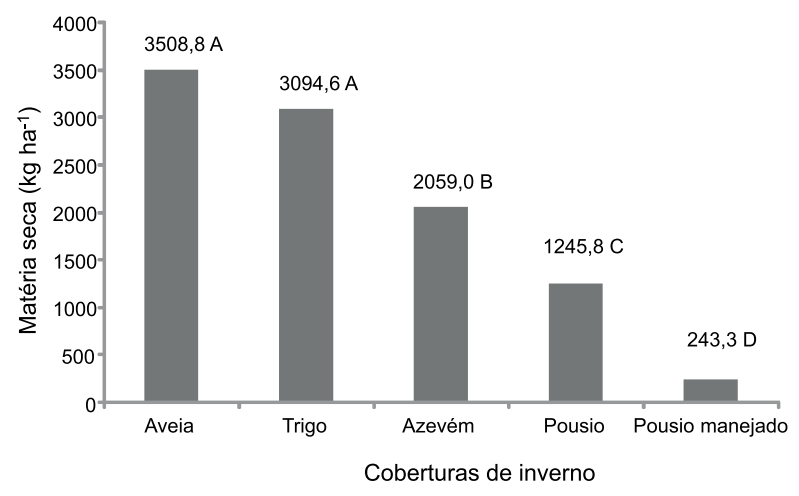

Médias seguidas de mesma letra não diferem entre si pelo teste de Tukey a $5 \%$ de probabilidade de erro.

Figura 2 - Matéria seca proporcionada pelas coberturas de inverno. Não-Me-Toque, RS.

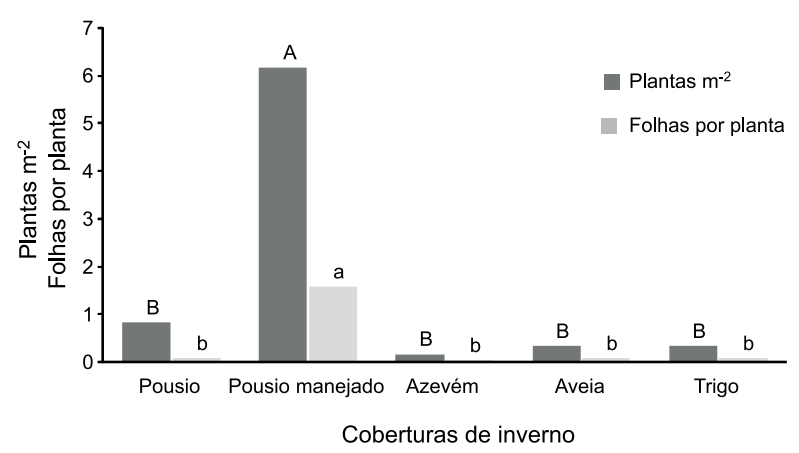

Colunas com a mesma letra maiúscula para a avaliação de plantas $\mathrm{m}^{-2}$ e minúscula para a avaliação de folhas por planta não diferem entre si pelo teste de Tukey a $5 \%$ de probabilidade.

Figura 3 - Número de plantas e de folhas por planta de E. heterophylla antes da dessecação das coberturas de inverno, realizada em 27 de outubro. Não-Me-Toque, RS. 
solos sem cobertura vegetal apresentarem geralmente maior amplitude térmica diária do que solos protegidos (Salton \& Mielniczuk, 1995).

Sob solo desnudo, as sementes de leiteiro próximas da superficie sofrem efeito térmico acentuado, passando rapidamente, e em maior número, de dormentes para quiescentes, permanecendo assim aptas à germinação (Theisen, 1998). Também uma explicação possivel para a reduzida densidade de E. heterophylla em solos com cobertura seria a redução da quantidade e modificação da qualidade da luz que atinge as sementes dessa espécie nos solos com palha na superfície (Rizzardi et al., 2006).

Na situação de pousio manejado, as plantas de E. heterophylla encontraram-se mais desenvolvidas que nos demais tratamentos, indicando que as sementes germinaram antes ou tiveram melhores condições de desenvolvimento em relação aos demais tratamentos (Figura 3), pelo fato de estarem em uma situação de menor competição e melhor acesso aos recursos de luz, água e nutrientes. A aplicação de 1.440 g e.a. ha ${ }^{-1}$ de glifosato $+3,6$ g i.a. ha ${ }^{-1}$ de metsulfurom-metílico realizada nas parcelas de pousio manejado não se mostrou capaz de evitar a emergência de E. heterophylla até o momento de se efetuar a dessecação para a semeadura da soja, que ocorreu dois meses após essa aplicação (Figura 3).

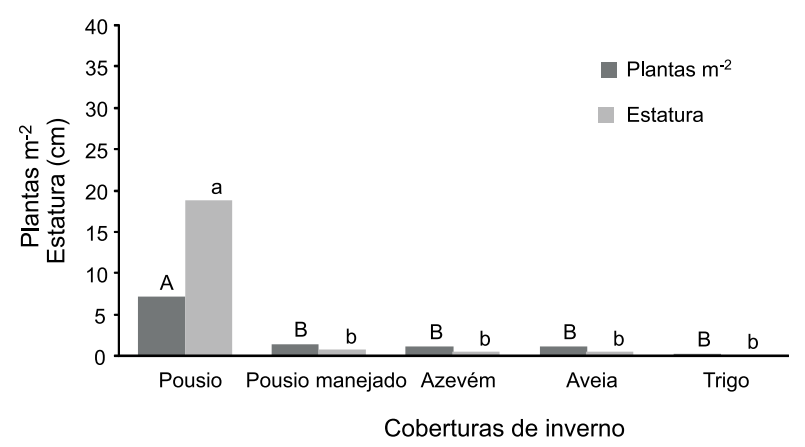

Colunas seguidas de mesma letra maiúscula para a avaliação de plantas $\mathrm{m}^{-2} \mathrm{e}$ minúscula para a avaliação de folhas por planta não diferem entre si pelo teste de Tukey a $5 \%$ de probabilidade.

Figura 4 - Número e altura de plantas de Conyza sp. antes da dessecação das coberturas de inverno, realizada em 27 de outubro. Não-Me-Toque, RS.
Para as espécies de Conyza spp., tanto a infestação quanto o estádio de desenvolvimento das plantas nas parcelas em pousio foram significativamente superiores aos dos demais tratamentos (Figura 4). Em trabalho avaliando a infestação de C. canadensis, Bruce \& Kells (1990) relatam que em áreas sob semeadura direta de soja, onde não se realiza cultivo durante o inverno ou as culturas são colhidas antecipadamente, ocorre intensa infestação dessa espécie. Paula et al. (2011) também relatam o efeito de áreas em pousio na infestação e desenvolvimento de Conyza spp. Nas parcelas de pousio manejado, a infestação e o desenvolvimento das plantas de buva foram interrompidos pela aplicação de $1.440 \mathrm{~g}$ e.a. ha ${ }^{-1}$ de glifosato $+3,6$ g i.a. ha-1 de metsulfurommetil (Figura 4).

No momento da semeadura da soja, 7 de dezembro, não foi constatada diferença significativa de infestação nem de estádio de desenvolvimento das plantas de $E$. heterophylla entre as diferentes coberturas de solo. Isso se deveu à dessecação realizada aos 41 DAS da soja para as coberturas de aveia, azevém, pousio e pousio manejado e ao efeito de cobertura de solo proporcionado pelo trigo e do controle químico de herbicidas específicos para essa cultura, já que essa parcela não recebeu nenhum tipo de aplicação química no momento de dessecação das demais coberturas vegetais (Figura 5). As plantas presentes nas parcelas no momento dessa avaliação foram

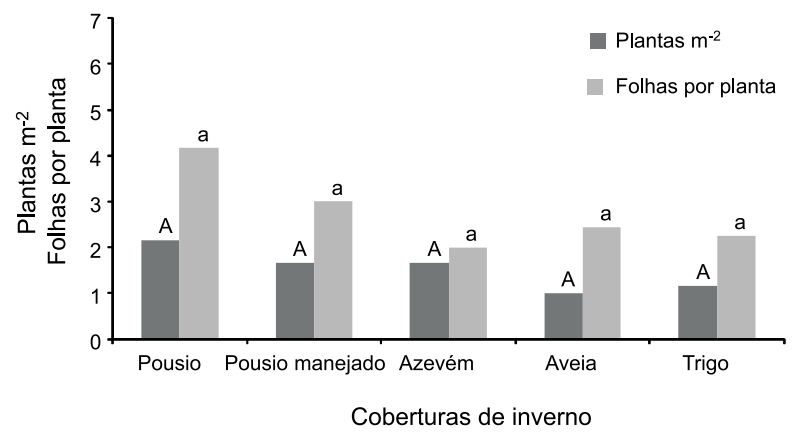

Colunas seguidas de mesma letra maiúscula para a avaliação de plantas $\mathrm{m}^{-2}$ e minúscula para a avaliação de folhas por planta não diferem entre si pelo teste de Tukey a $5 \%$ de probabilidade.

Figura 5 - Número de plantas e de folhas por planta de E. heterophylla após a semeadura da soja. Não-MeToque, RS. 
provenientes de germinações ocorridas após a dessecação das coberturas de inverno. Isso explica a uniformidade no número de plantas por área e no estádio de desenvolvimento delas.

Diferentemente do que ocorreu com E. heterophylla, que teve a infestação reduzida e equiparada entre todos os tratamentos no momento da semeadura da soja, para a espécie Conyza spp., os níveis de infestação e também a estatura das plantas continuaram aumentando, principalmente nas parcelas mantidas em pousio (Figura 6), demonstrando a ineficiência desse tipo de manejo e também a resistência adquirida por essa espécie ao glifosato.

Para controle de Conyza spp., aos 28 DAAS, foram significativos os três efeitos simples e todas as quatro interações. O controle de buva foi facilitado quando a implantação da soja foi antecedida pelas coberturas de aveia, trigo ou azevém. Nessas situações, o nível de controle ficou acima de 90\%, não havendo diferença significativa entre os tratamentos (Figura 7). O cultivo da área atrasa praticamente um a dois meses a emergência de buva, o que reduz a quantidade e o porte das plantas por ocasião da dessecação para semeadura da soja (Bianchi, 2010), proporcionando melhores condições para atuação dos herbicidas utilizados.

O cenário inverso deu-se nas áreas em pousio, onde os niveis de controle ficaram abaixo de $75 \%$ para qualquer tipo de intervenção que se realizou antes ou após a semeadura,

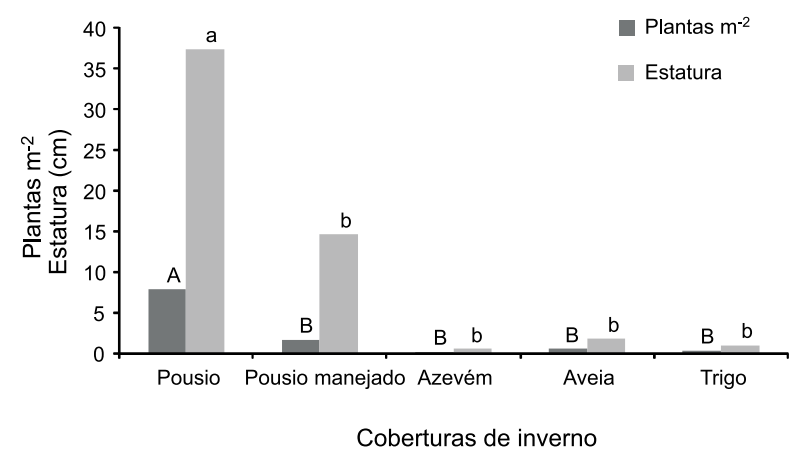

Médias seguidas de mesma letra maiúscula para a avaliação de plantas $\mathrm{m}^{-2}$ e minúscula para a avaliação de estatura não diferem entre si pelo teste de Tukey a $5 \%$ de probabilidade.

Figura 6 - Número e altura de plantas de Conyza sp. após a semeadura da soja. Não-Me-Toque, RS.

Planta Daninha, Viçosa-MG, v. 32, n. 4, p. 683-697, 2014
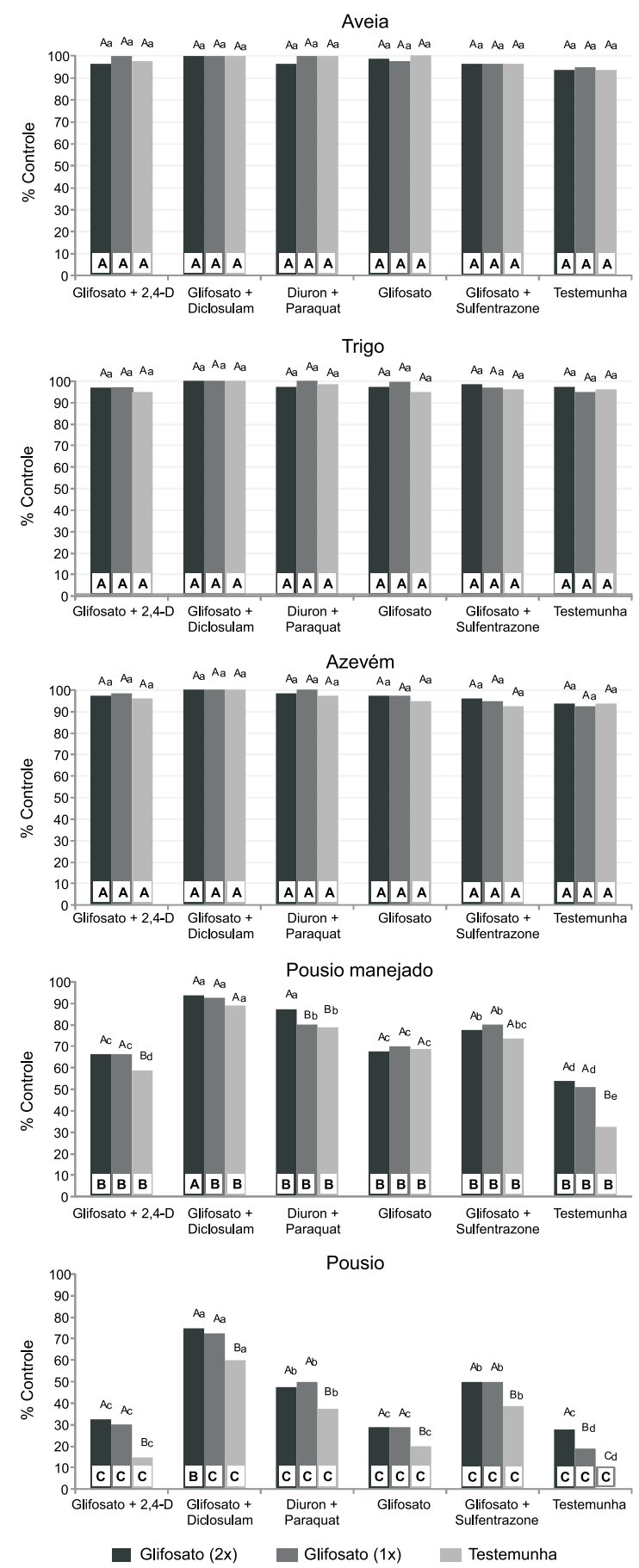

Letras maiúsculas na base da barra do gráfico comparam médias entre as coberturas de inverno; letras maiúsculas acima da barra comparam médias dentro dos tratamentos de pré-semeadura; e letras minúsculas comparam médias entre os tratamentos de présemeadura. Médias com letras iguais não diferem entre si pelo teste de Tukey a $5 \%$ de probabilidade.

Figura 7 - Controle de Conyza spp. aos 28 dias após a aplicação sequencial, em função de herbicidas e coberturas de inverno. Não-Me-Toque, RS. 
ou mesmo na combinação das duas operações de controle (pré ou pós).

Um aumento significativo nos níveis de controle foi atingido no tratamento de pousio manejado, quando comparado com o pousio (Figura 7). No entanto, esse aumento não foi suficiente para atingir niveis de controle similares aos dos tratamentos que possuíam a cobertura vegetal de aveia, trigo ou azevém. $\mathrm{Na}$ situação de pousio manejado, somente a estratégia de utilização de glifosato + diclosulam na pré-semeadura, aliado a duas aplicações de glifosato em pós-emergência da soja, foi capaz de equiparar-se estatisticamente aos mesmos tratamentos realizados nas coberturas de aveia, trigo ou azevém.

Para o controle de E. heterophylla, aos 28 DAAS, foram significativos os três efeitos simples e todas as quatro interações. Em áreas onde foi utilizada aveia como cobertura de inverno, o controle sequencial com glifosato em pós-emergência dispensa a necessidade do controle químico em pré-semeadura da soja para atingir niveis de controle de leiteiro acima de $90 \%$. Comparando-se o tratamento com uma única aplicação de glifosato em pósemergência entre os tratamentos de présemeadura, os tratamentos contendo 2,4-D ou mesmo a testemunha diferiram dos demais (Figura 8).

Para obter niveis de controle de leiteiro acima de $90 \%$ quando a soja é semeada em resteva de trigo, faz-se necessária a utilização de algum tipo de controle químico présemeadura e também de no mínimo uma aplicação de glifosato em pós-emergência da soja, com exceção do tratamento présemeadura com 2,4-D, que necessita de duas aplicações em pós-emergência para atingir esse mesmo nível de controle. A não utilização de controle químico em pré-semeadura (testemunha) resultou em baixos niveis de controle mesmo com o uso de aplicação sequencial em pós-emergência da soja (Figura 8).

O controle de leiteiro em áreas onde se cultivou o azevém como cobertura de solo ficou facilitado quando no controle plantas daninhas em pré-semeadura utilizou-se o tratamento glifosato + diclosulam; nessa situação, temse menos dependência das aplicações de pósemergência. Nesse tipo de cobertura vegetal,
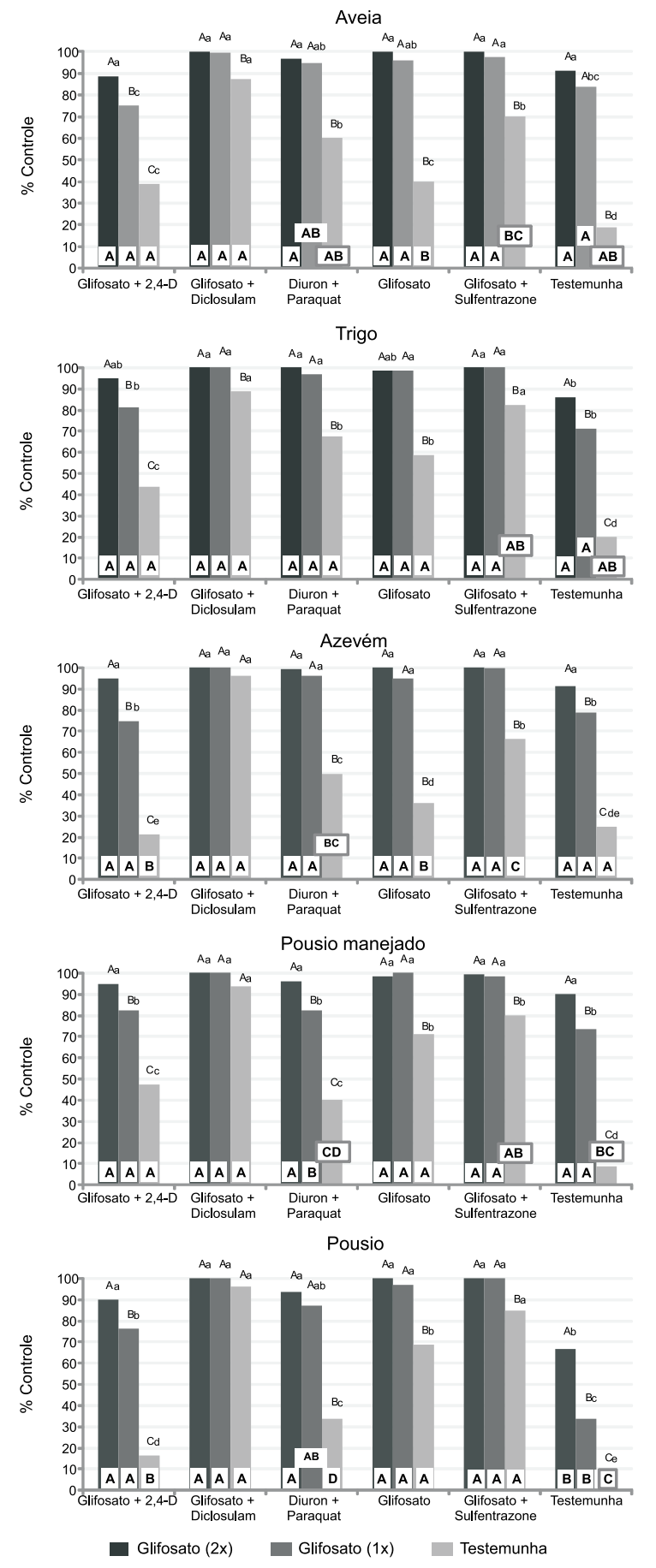

Letras maiúsculas na base da barra do gráfico comparam médias entre as coberturas de inverno; letras maiúsculas acima da barra comparam médias dentro dos tratamentos de pré-semeadura; e letras minúsculas comparam médias entre os tratamentos de présemeadura. Médias com letras iguais não diferem entre si pelo teste de Tukey a $5 \%$.

Figura 8 - Controle de Euphorbia heterophylla aos 28 dias após a aplicação sequencial, em função de herbicidas e coberturas de inverno. Não-Me-Toque, RS. 
foi possivel atingir niveis de controle de leiteiro acima de 90\% independentemente do tipo de controle químico adotado em présemeadura, bastando que para isso adote-se a aplicação sequencial em pós-emergência da soja. Caso a escolha seja fazer somente uma aplicação em pós-emergência, deve-se realizar algum tipo de controle químico em pré-semeadura, evitando-se, no entanto, o tratamento glifosato + 2,4-D (Figura 8) .

Em áreas de pousio que foram manejadas no inverno, a utilização de glifosato + diclosulam na pré-semeadura ajudou a flexibilizar a aplicação do controle químico em pós-emergência. Nos tratamentos em que se utilizou glifosato ou glifosato + sulfentrazone na pré-semeadura, no mínimo uma aplicação de glifosato em pós-emergência se fez necessária. Já nas situações sem controle químico em pré-semeadura (testemunha) ou da utilização de glifosato $+2,4-\mathrm{D}$, obrigatoriamente precisou-se de duas aplicações na pós-emergência da soja (Figura 8).

Quando se fez o controle químico de présemeadura com glifosato + diclosulam, eliminou-se a necessidade de controle químico em pós-emergência da soja para controle de E. heterophylla. Quando o tratamento em pré-semeadura foi realizado com diuron + paraquat, glifosato ou glifosato + sulfentrazone, tornou-se necessário no mínimo uma aplicação para manter os niveis de controle acima de $85 \%$.

$\mathrm{Na}$ situação de pousio, a não realização de um controle químico em pré-semeadura (testemunha) tornou extremamente dificil o controle de $E$. heterophylla em pós-emergência, pois nessa situação as plantas estavam em estádio maior de desenvolvimento e em maior número na área, o que tornou ineficaz a aplicação sequencial em pós-emergência (Figura 8).

A avaliação de controle no estádio $R_{6}$ foi feita para $E$. heterophylla, já que essa era a espécie mais frequente nas parcelas. As plantas de buva ainda permaneciam em muitas parcelas, mas já secas.

Quando a cobertura de inverno foi com aveia, não se observou diferença entre se fazer uma ou duas aplicações em pós-emergência. No entanto, no mínimo uma aplicação se fez necessária para atingir niveis de controle de leiteiro acima de 90\% (Figura 9). Nessa situação de cobertura de solo, eliminou-se também a necessidade de uma aplicação em présemeadura, já que, nas parcelas sem esta aplicação, os valores ficaram acima de $90 \%$ mesmo fazendo-se uma única aplicação de glifosato em pós-emergência da soja.

Quando a semeadura da soja deu-se sobre resteva de trigo, o controle químico em pósemergência da soja ficou mais dependente de aplicações sequenciais, visto que estas foram significativamente melhores que as aplicações únicas para controle de leiteiro, retornando valores, em sua maioria, próximos a $100 \%$ de controle. Nas situações de uso de glifosato ou diuron + paraquat em pré-semeadura, observou-se controle inferior quando se fez somente uma aplicação em pósemergência. Quando se avaliou o efeito das aplicações únicas ou sequenciais em pósemergência, observou-se independência do efeito dos tratamentos de pré-semeadura (Figura 9).

Para áreas com cobertura de inverno formada por azevém, a estratégia de aplicações sequenciais em pós-emergência mostrou-se mais eficiente no controle de leiteiro, sobretudo quando não se fez nenhum tipo de aplicação no momento da semeadura da soja ou mesmo quando foi utilizado somente glifosato $+2,4-\mathrm{D}$ como agentes dessecantes. O baixo desempenho da mistura glifosato + 2,4-D no controle de leiteiro deu-se em função da reinfestação das parcelas. Este tratamento ficou bastante prejudicado pelo fato de ter sido realizado 22 dias antes da semeadura da soja, o que propiciou essa reinfestação.

No pousio manejado, visando ao controle de leiteiro, a melhor estratégia foi adotar algum tipo de controle químico em pré-semeadura da soja. Isso possibilitou niveis de controle acima de $90 \%$ quando combinado com uma aplicação em pós-emergência e a possibilidade de uma sequencial em casos extremos. Quando não se efetuou o controle químico no momento da semeadura da soja, foram necessárias duas aplicações em pós-emergência para atingir niveis de controle acima de $90 \%$.

Se nas áreas de pousio manejado o controle químico em pré-semeadura foi uma boa 


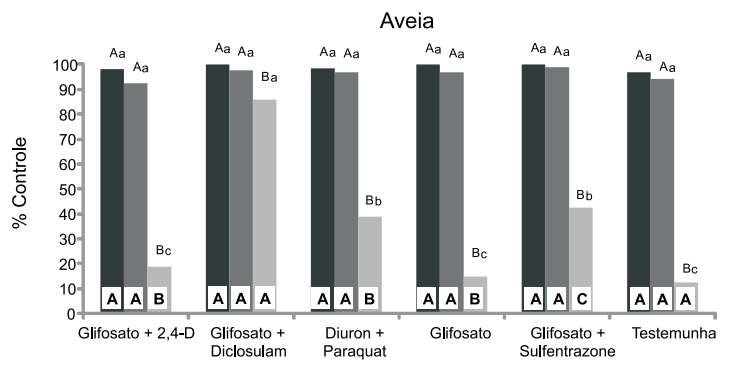

alternativa, em áreas de pousio essa alternativa se tornou obrigatória. Caso contrário, mesmo fazendo duas aplicações em pósemergência da soja, o controle de leiteiro será insatisfatório.

Para a altura de plantas, tanto os efeitos simples de coberturas de inverno e pós-emergência quanto o efeito duplo de pré-semeadura $\mathrm{x}$ pós-emergência foram significativos. As coberturas de aveia e trigo foram as que proporcionaram maior desenvolvimento das plantas de soja (Figura 10), provavelmente relacionado à menor competição com as plantas daninhas. O pousio foi a cobertura de solo que mais reduziu o porte das plantas de soja. Em média, as plantas ficaram $6,1 \mathrm{~cm}$ mais baixas no pousio do que as plantas cultivadas onde havia a cobertura de aveia-preta.

A aplicação sequencial de glifosato reduziu a altura média das plantas em $2,0 \mathrm{~cm}$, em comparação com as parcelas com uma aplicação única de glifosato (Figura 11). No entanto, esse possivel resultado de fitointoxicação não foi significativo nas avaliações visuais. Foloni et al. (2005) relatam que a altura das plantas de soja foi influenciada pelos tratamentos herbicidas, mas não afetou a produtividade da soja, o que foi similar neste trabalho.

Quanto à interação dos tratamentos de pré-semeadura e pós-emergência, apenas na aplicação sequencial houve diferença significativa entre a testemunha e os demais

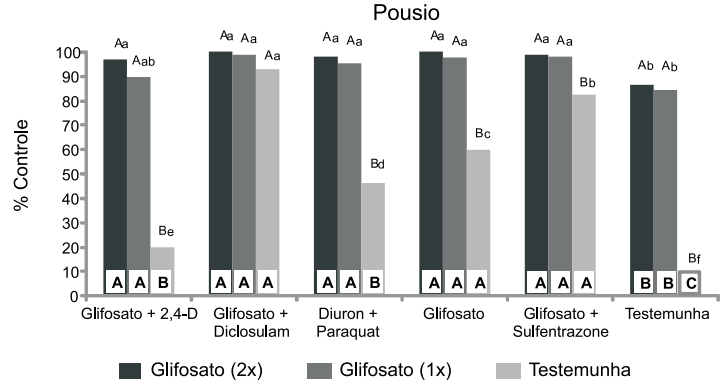

Letras maiúsculas na base da barra do gráfico comparam médias entre as coberturas de inverno; letras maiúsculas acima da barra comparam médias dentro dos tratamentos de pré-semeadura; e letras minúsculas comparam médias entre os tratamentos de présemeadura. Médias com letras iguais não diferem entre si pelo teste de Tukey a $5 \%$.

Figura 9 - Controle de Euphorbia heterophylla no estádio R6 da soja, em função de herbicidas e coberturas de inverno. Não-Me-Toque, RS.

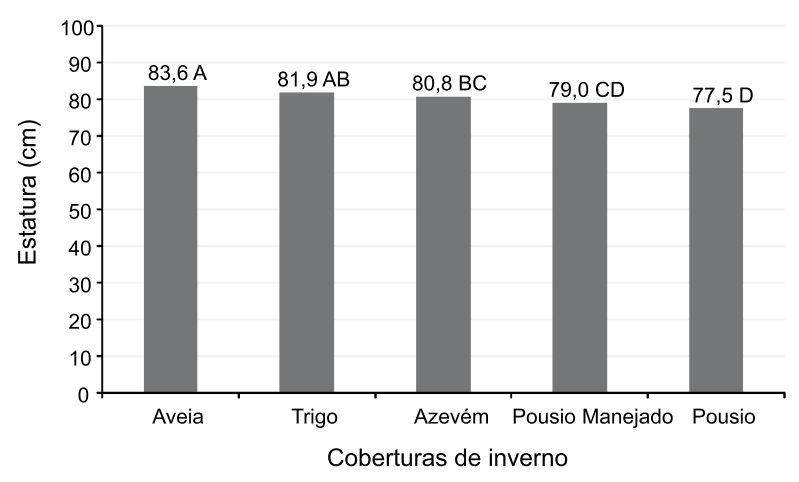

Mádias seguidas de mesma letra não diferem entre si pelo teste de Tukey a $5 \%$ de probabilidade.

Figura 10 - Altura de plantas de soja em função do tipo de cobertura de inverno, na média dos tratamentos herbicidas. Não-Me-Toque, RS. 
tratamentos em pré-semeadura; na situação em que não se utilizou nenhum produto na pré-semeadura (testemunha) e se realizaram duas aplicações de glifosato em pós-emergência, as plantas ficaram menores (Figura 12).

Onde se utilizou somente glifosato no controle em pré-semeadura da soja ou mesmo nenhum produto (testemunha), a altura das plantas de soja foi significativamente reduzida quando da aplicação sequencial de glifosato em pós-emergência da soja (Figura 12), confirmando o que foi relatado para a Figura 11 quanto ao efeito das aplicações sequenciais no porte das plantas. Já quando o produto utilizado no momento da semeadura foi glifosato + sulfentrazone, a redução deu-se pela não aplicação em pós-emergência, possivelmente pelos efeitos de matocompetição, já que nessas parcelas o controle médio ficou abaixo de $70 \%$.

Para a produtividade, somente as interações duplas foram significativas. Independentemente dos tratamentos utilizados em présemeadura da soja, as melhores coberturas foram aveia, trigo, azevém e pousio manejado. No entanto, somente aveia e trigo diferiram do tratamento mantido em pousio.

Sem considerar o efeito das coberturas e dos tratamentos em pós-emergência, os tratamentos pré-semeadura que se destacaram foram os que empregaram os ingredientes ativos glifosato + diclosulam ou glifosato + sulfentrazone, sendo os únicos que diferiram da testemunha. Embora os tratamentos com glifosato $+2,4-\mathrm{D}$, diuron + paraquat ou glifosato não tenham diferido dos tratamentos com glifosato + diclosulam ou glifosato + sulfentrazone, também não diferiram da testemunha.

Comparando o efeito dos tratamentos pré-semeadura testados dentro de cada tipo de cobertura, somente nas parcelas mantidas em pousio ele foi significativo; nesta situação, os únicos tratamentos que diferiram da testemunha foram glifosato, glifosato + sulfentrazone e glifosato + 2,4-D (Figura 13).

Já o efeito das coberturas na produtividade da soja não foi significativo quando foram utilizados glifosato $+2,4-\mathrm{D}$, glifosato ou glifosato + sulfentrazone como tratamento em pré-semeadura (Figura 13). Quando os produtos

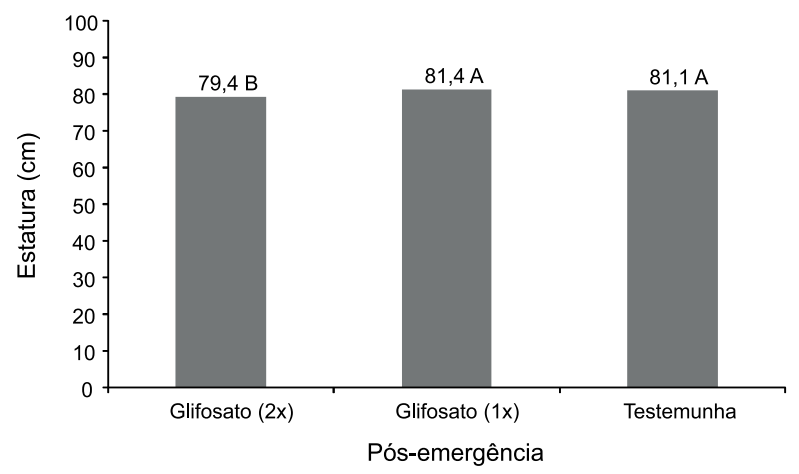

Médias seguidas de mesma letra não diferem entre si pelo teste de Tukey a $5 \%$ de probabilidade.

Figura 11 - Altura de plantas de soja em função dos herbicidas utilizados em pós-emergência, na média de coberturas de inverno e de herbicidas em pré-semeadura. Não-MeToque, RS.

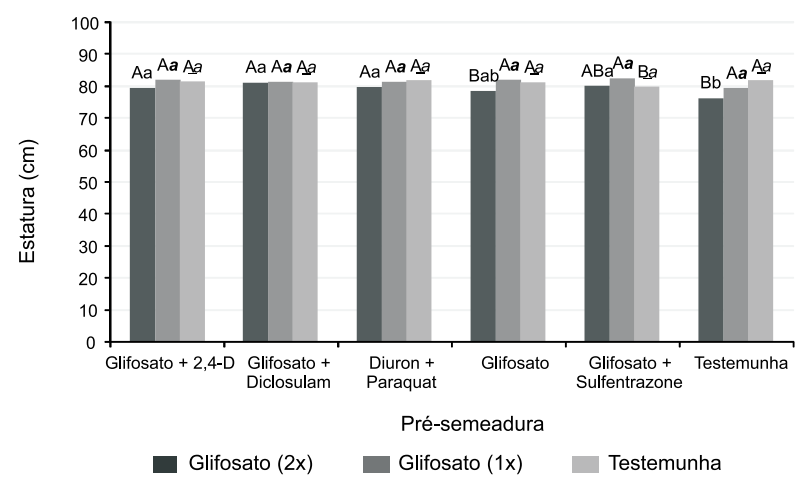

Médias seguidas de mesma letra maiúscula dentro de cada tratamento em pré-semeadura e minúscula entre os tratamentos de présemeadura não diferem entre si pelo teste de Tukey a $5 \%$ de probabilidade.

Figura 12 - Altura de plantas de soja em função de herbicidas em pré-semeadura e de pós-emergência, na média de coberturas de inverno. Não-Me-Toque, RS.

glifosato + diclosulam foram utilizados como tratamento em pré-semeadura, os melhores resultados foram obtidos quando se tinha uma cobertura de solo bem implantada, como é o caso das coberturas de aveia, trigo e azevém. Essa situação se mostrou mais evidente quando nenhum tipo de produto foi utilizado no momento da semeadura da soja (testemunha), em que as parcelas cobertas com aveia, trigo ou azevém mostraram-se significativamente mais produtivas do que as parcelas mantidas em pousio (Figura 13). 


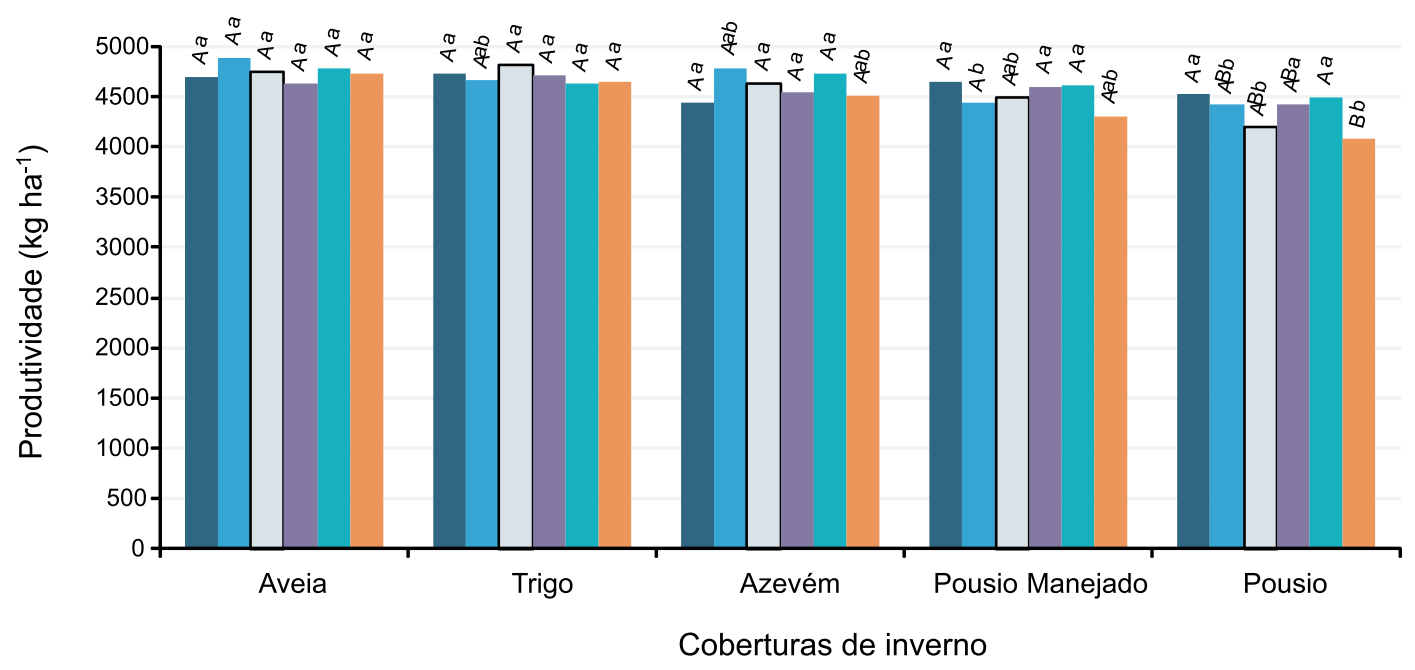

Glifosato + 2,4-D Glifosato + Diclosulam $\square$ Diuron + Paraquat $\square$ Glifosato $\square$ Glifosato + Sulfentrazone $\square$ Testemunha

Colunas seguidas com a mesma letra maiúscula dentro de cada cobertura de inverno e minúscula entre as coberturas não diferem entre si pelo teste de Tukey a $5 \%$ de probabilidade.

Figura 13 - Produtividade da soja em função das coberturas de inverno e dos herbicidas de pré-semeadura, na média dos herbicidas de pós-emergência. Não-Me-Toque, RS.

Nos tratamentos onde foram utilizados os ingredientes ativos diuron + paraquat, todas as coberturas ou mesmo o fato de fazer-se o controle químico nas áreas em pousio durante o inverno (pousio manejado) mostraram-se melhores do que os tratamentos em que as parcelas ficaram em pousio durante todo o período que antecedeu a semeadura da soja.

Com relação às aplicações em pós-emergência da soja, a análise mostra que, de maneira geral, quando se desconsidera o efeito dos tratamentos em pré-semeadura, não existe diferença significativa entre se fazer uma ou duas aplicações de glifosato em pós-emergência. Contudo, no mínimo uma aplicação se fez necessária.

Analisando o efeito das aplicações em pós-emergência dentro de cada nível dos tratamentos em pré-semeadura utilizados, verifica-se que a resposta foi a mesma para os tratamentos com glifosato $+2,4-\mathrm{D}$, glifosato, glifosato + sulfentrazone ou mesmo quando não se realizou nenhum tipo de aplicação antes do plantio da soja (testemunha), não havendo diferença entre se fazer uma ou duas aplicações de glifosato na pós-emergência da soja. No entanto, quando o tratamento foi realizado com glifosato + diclosulam, não foi encontrada diferença significativa entre os tratamentos de pós-emergência testados. Entretanto, para o tratamento com diuron + paraquat, somente a estratégia de duas aplicações de glifosato em pós-emergência diferiu da testemunha (Figura 14).

Analisando a interação entre os efeitos das coberturas e dos tratamentos em pós-emergência, verificou-se que, com exceção do tratamento de pousio manejado, onde uma aplicação de glifosato em pós-emergência da soja não diferiu da testemunha, todos os demais tratamentos mostraram que a aplicação de uma ou duas doses de glifosato em pósemergência foi melhor do que a testemunha (Figura 15).

De maneira geral, com duas aplicações de glifosato em pós-emergência fica-se menos dependente do tipo de cobertura vegetal para se obter um bom resultado, porém, em situações de pousio, mesmo com essa estratégia não se evita uma perda significativa de produtividade. À medida que o número de aplicações de glifosato em pós-emergência é reduzido, aumenta-se a dependência de se ter uma boa cobertura vegetal implantada para 


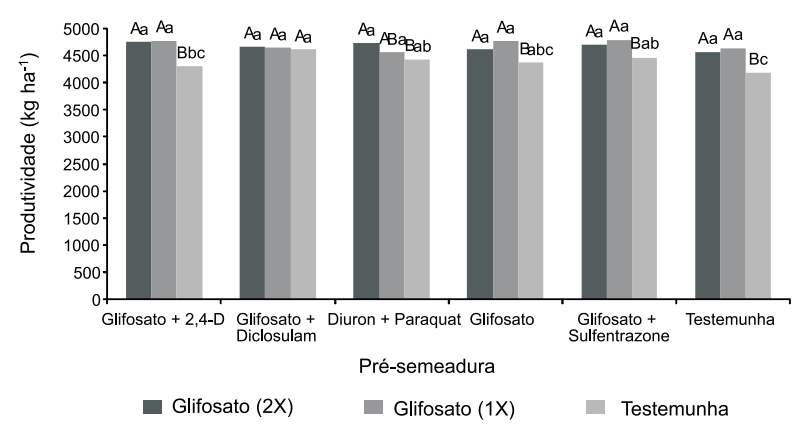

Colunas seguidas com a mesma letra maiúscula dentro de cada tratamento de pré-semeadura e minúscula entre os tratamentos de pré-semeadura não diferem entre si pelo teste de Tukey a $5 \%$ de probabilidade.

Figura 14 - Produtividade da soja em função dos herbicidas utilizados em pré-semeadura e pós-emergência, na média de coberturas de inverno. Não-Me-Toque, RS.

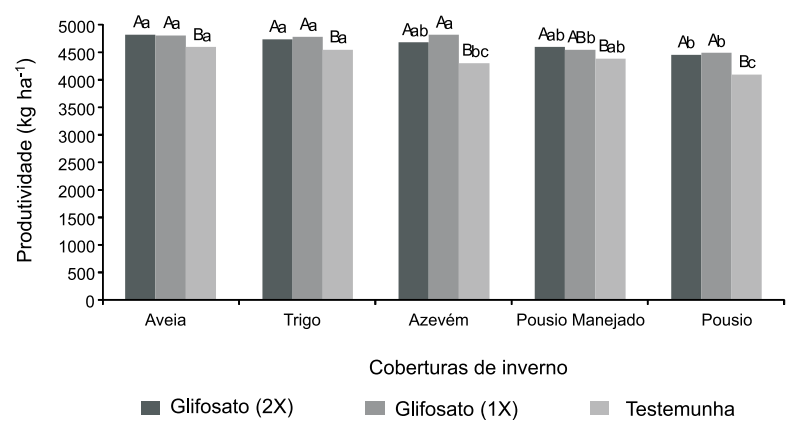

Colunas seguidas com a mesma letra maiúscula dentro de cada cobertura de inverno e minúscula entre as coberturas não diferem entre si pelo teste de Tukey a $5 \%$ de probabilidade.

Figura 15 - Produtividade da soja em função das coberturas de inverno e dos herbicidas de pós-emergência, na média dos herbicidas de pré-semeadura. Não-Me-Toque, RS.

não haver redução de produtividade. Mesmo a aplicação de herbicida na área em pousio no inverno (pousio manejado) não foi suficiente para evitar perda de produtividade significativa, quando comparada com as demais coberturas (aveia, trigo e azevém), na situação de uma única aplicação de glifosato em pós-emergência (Figura 15).

Diante dos resultados obtidos, constatouse que as coberturas de inverno são importantes ferramentas no manejo de plantas daninhas eudicotiledôneas em soja. Diversas são as opções de cobertura de inverno que possibilitam o bom manejo dessas espécies, mas áreas em pousio contribuem para a proliferação e dificuldade de controle das plantas daninhas.

O controle químico em pré-semeadura da soja, principalmente com produtos que tenham mecanismos de ação diferentes daqueles do glifosato e com efeito residual, é um importante aliado na preservação da tecnologia de soja Roundup Ready ${ }^{\circledR}$, quanto à prevenção dos casos de resistência ao glifosato.

\section{AGRADECIMENTOS}

Ao Conselho Nacional de Desenvolvimento Científico e Tecnológico - CNPq, pela Bolsa Produtividade em Pesquisa. À Fundação de Amparo à Pesquisa do Estado do Rio Grande do Sul - Fapergs, pelo auxílio financeiro (Proc. PqG 06/2010).

\section{LITERATURA CITADA}

AITA, C. et al. Plantas de cobertura de solo como fonte de nitrogênio ao milho. R. Bras. Ci. Solo, v. 25, n. 1, p. $157-165,2001$.

BIANCHI, M. A. Manejo de buva na entre-safra do cultivo de soja. In: REUNIÃO DE PESQUISA DA SOJA DA REGIÃO SUL, 38., 2010, Cruz Alta, RS. Anais... Cruz Alta: FUNDACEP FECOTRIGO, 2010. 209 p.

BRUCE, J.; KELLS, J. Horseweed (Conyza canadensis) control. in no-tillage soybeans (Glycine max) with preplant and preemergence herbicides. Weed Technol., v. 4, n. 3, p. 642-647, 1990.

BUHLER, D. D. Challenges and opportunities for integrated weed management. Weed Sci., v. 50, n. 3, p. 273-280, 2002.

CARDENAS, J. Tropical weeds-malezas tropicales. Bogotá: Instituto Colombiano Agropecuário, 1972. v. 1. $341 \mathrm{p}$.

CLIVE, J. Global status of commercialized Biotech/GM Crops: 2010. Ithaca: ISAAA, 2010. (ISAAA Brief, 42)

EMPRESA BRASILEIRA DE PESQUISA AGROPECUÁRIA - EMBRAPA. Centro Nacional de Pesquisa de Solos. Sistema brasileiro de classificação de solos. Brasília: Embrapa Produção de Informação; Rio de Janeiro: Embrapa Solos, 1999. 412 p.

FOLONI, L. L. et al. Aplicação de glifosato em pósemergência, em soja transgênica cultivada no cerrado. R. Bras. Herbic., v. 4, n. 3, p. 47-58, 2005. 
GONÇALVES, C. N. et al. Sucessões de culturas com plantas de cobertura e milho em plantio direto e sua influência sobre o nitrogênio no solo. R. Bras. Ci. Solo, v. 24, n. 1, p. 153-159, 2000 .

KISSMANN, K. G.; GROTH, D. Plantas infestantes e nocivas. 2.ed. São Paulo: BASF, 1999. 972 p.

LAZAROTO, C. A. et al. A. Biologia e ecofisiologia de buva (Conyza bonariensis e Conyza canadensis). Ci. Rural, v. 38, n. 3, p. 852-860, 2008.

MATEUS, G. P. et al. Palhada do sorgo de guiné gigante no estabelecimento de plantas daninhas em área de plantio direto. Pesq. Agropec. Bras., v. 39, n. 6, p. 539-542, 2004.

PAUlA, J. M. et al. Manejo de Conyza bonariensis resistente ao herbicida glifosato. Planta Daninha, v. 29, n. 1, p. 217-227, 2011.

RIZZARDI, M. A. et al. Controle de plantas daninhas em milho em função de quantidades de palha de nabo forrageiro.

Planta Daninha, v. 24, n. 2, p. 263-270, 2006.

ROMAN, E. et al. Como funcionam os herbicidas: da biologia à aplicação. Passo Fundo: Gráfica Editora Berthier, 2007. $160 \mathrm{p}$.

SALTON, J. C.; MIELNICKZUK, J. Relações entre sistemas de preparo, temperatura e umidade de um podzólico vermelho escuro de Eldorado do Sul (RS). R.Bras. Ci. Solo, v. 19, n. 2, p. 313-319, 1995.

SILVA, P. R. F. et al. Estratégias de manejo de coberturas de solo no inverno para cultivo do milho em sucessão no sistema semeadura direta. Ci. Rural, v. 36, n. 3, p. 1011-1020, 2006.
THEISEN, G. Influência de palha de aveia preta em papuã (Brachiaria plantaginea (Link) Hitch.) e seu impacto em soja. 1998. 87 f. Dissertação (Mestrado em Agronomia) - Universidade Federal do Rio Grande do Sul, Porto Alegre, 1998.

TREZZI, M. M. et al. Local de absorção de fomesafen como mecanismo de resistência em biótipo de Euphorbia heterophylla resistente aos inibidores da Protox.

Planta Daninha, v. 27, n. 1, p. 139-148, 2009.

VARGAS, L. et al. Resistência de plantas daninhas à herbicidas. Viçosa, MG: 1999. 131 p.

VARGAS, L.; ROMAN, E. S. Manual de manejo e controle de plantas daninhas. Passo Fundo: Embrapa Trigo, 2008. $780 \mathrm{p}$.

VIDAL, R. A.; MEROTTO Jr., A. Herbicidologia. Porto Alegre: 2001. $152 \mathrm{p}$.

VIDAL, R. A. et al. Glyphosate-resistant weeds of South America: an overview. Agro-Chem. Agric., v. 72, n. 1, p. 72-72, 2007.

VIDAL, R. A.; WINKLER, L. M. Resistência de plantas daninhas: seleção ou indução à mutação pelos herbicidas inibidores de acetolactato sintase (ALS). Pestic.:

R. Ecotoxicol. Meio Amb., v. 12, n. 1, p. 31-42, 2002.

WEAVER, S. E. The biology of Canadian weeds. 115. Conyza canadensis. Canadian J. Plant Sci., v. 81, n. 1, p. 867-875, 2001. 